\title{
Türkiye'de Döviz Kuru ve Faiz Oranı Arasındaki Etkileşim: Türkiye için Ampirik Kanıtlar ${ }^{1}$
}

\author{
The Interaction Between Exchange Rates and Interest Rates in Turkey: \\ Empirical Evidences for Turkey
}

\author{
Aslı GÜLER, Ordu Üniversitesi, Türkiye, asliguler24@hotmail.com \\ Orcid No: 0000-0002-2900-1184
}

\begin{abstract}
Öz: Finansın küreselleșmesi sonucu sermaye giriș çılkşlarının hız kazanması, döviz kurlarında așırı dalgalanmalar meydana getirmekte ve döviz kurlarına ilișkin belirsizliği arttırarak ileriye dönük tahmin yapmayı oldukça güçleștirmektedir. Teorik bilgiye göre döviz kurları ve faiz oranları arasında sıkı bir ilişki söz konusudur ve sermayenin faize duyarlılığının yüksek olduğu ülkelerde para politikası aracılı̆̆yla kurdaki dalgalanmalar slnırlandırmak mümkün olmaktadır.

Bu çalışmanın amacl, Türkiye'de para politikası faiz oranı ve piyasa faiz oranlarının döviz kurları üzerindeki etkilerini ampirik olarak sorgulamaktır. Bu bağlamda nominal döviz kuru ile para politikası faiz oranı, ortalama fonlama maliyeti ve gösterge faiz oranı arasındaki dinamik ilișkiler, VAR metodolojisi ve ARDL sinır testi aractlı̆̆ ile 2011:01 ile 2018:05 dönemine ait ayllk veriler kullanilarak araștırılmıștır. Elde edilen sonuçlar TCMB'nin resmi politika faiz oranlar (politika faizi ve ortalama fonlama maliyeti) ile nominal döviz kuru arasinda ne klsa ne de uzun dönemde anlamlı bir iliski olmadığına isaret etmektedir. Buna karsın, piyasa faizi olarak modele dahil edilen gösterge tahvil faizi ile nominal döviz kuru arasında pozitif yönlü anlamlı bir ilişki olduğu tespit edilmiştir. Sonuçlar birlikte değerlendirildiğinde, merkez bankasının piyasa faiz oranların resmi faiz oranlart ile yönlendirmek suretiyle döviz kurlarını dolaylı yoldan etkileyebileceği sonucuna ulaşılmıştır.
\end{abstract}

Anahtar Kelimeler: Döviz Kuru, Faiz oranı, Para Politikasl, ARDL Sinır Testi

JEL Sintflandırmasi: F31, E43, E47, E52

\begin{abstract}
The acceleration of capital inflows as a result of the globalization of finance causes excessive fluctuations in exchange rates and increases uncertainty about exchange rates, making it difficult to make predictions. According to theoretical knowledge, there is a close relationship between exchange rates and interest rates and it is possible to limit the fluctuations in exchange rates through monetary policy in countries where capital movements are highly sensitive to interest rates.

The aim of this study is to question empirically the impacts of monetary policy interest rates and market interest rates on exchange rates in Turkey's. In this context, the dynamic relationships between the exchange rates and interest rates in Turkey were investigated by using monthly data for the period through 2011:01-2018:05 with VAR method and the ARDL cointegration test. The results indicate that there is no significant relationship between the CBRT's official policy interest rates (policy rate and average funding cost) and the nominal exchange rate either in the short or long term. On the other hand, there is a positive correlation between the benchmark bond rate and exchange rate. When the results are evaluated, it is understood that the central bank may affect the exchange rates indirectly by directing the market interest rates with the official interest rates.
\end{abstract}

Keywords: Exchange Rate, Interest Rate, Monetary Policy, ARDL Bound Test JEL Classification: F31, E43, E47, E52

\section{Giris}

Döviz kurları ve faiz oranı etkileşimleri farklı kesimlerden teorisyenlerin ve politika yapıcıların önemli ölçüde dikkatini çeken ve farklı yaklaşımların ortaya atıldığı bir politika konusudur. Özellikle 1980'lerden sonar, gerçekleşen sınır ötesi sermaye ve mal transferlerinin çok büyük boyutlara ulaşması ve döviz kurlarının dalgalanmaya bırakılması, döviz kurlarının istikrarının korunmasını da bir politika meselesi haline getirmiştir. Bugün gelinen noktada, döviz kurlarında meydana gelen büyük sayılmayacak dalgalanmaların bile ekonomik aktörlerin mali yapılarını nasıl etkilediği düşünülecek olursa, büyük çaplı kur hareketlerinin ekonomi üzerinde ne derece tahrip edici olabileceği aşikar olacaktır.

Para politikasına ilişkin literatürde, faiz oranlarının döviz kurlarının istikrarının sağlanması amacıyla kullanılabileceğine dair yaygın bir görüş vardır. Bu geleneksel görüşe göre, nominal faiz oranlarının yükseltilmesi reel faizlerin de yükselmesine neden olacaktır. Reel faizlerin yükselmesi ise yabancı sermaye girişini tetikleyerek döviz kurunun düşmesine, ulusal paranın ise değer kazanmasına yol açacaktır. Ancak teorik ve ampirik literatürde geleneksel görüşle çelişen çalışmalara rastlanmaktadır. Örneğin Dornbusch (1976: 1173), döviz kurları ve faiz oranının uyum sürecinin büyük ölçüde ekonomik yapıya bağlı olarak değişebileceğini savunmaktadır. Dornbusch’a göre döviz kurlarının faiz oranlarına vereceği tepki, talebin gelir ve fiyat esnekliklerine bağlıdır. Dolayısı ile faiz oranları düşürüldüğünde ya da yükseltildiğinde mutlaka döviz kurlarının aşırı yükselmesi ya da düşmesi beklenmemelidir.

Teorik yaklaşımların ulaştıkları bu çelişkili sonuçlar uygulamada da karşılığını bulmaktadır. Bazı durumlarda döviz kuru dalgalanmalarına faiz oranı ile gerçekleştirilen müdahaleler başarılı sonuçlar doğururken, bazı durumlarda ise faiz politikası kurlar üzerinde beklenilenin aksi etkiler meydana getirebilmektedir. Örneğin yaşanan bazı para krizleri sırasında

${ }^{1}$ Bu çalışmanın ilk versiyonu II. International Conference on Empirical Economics and Social Sciences (ICEESS’ 19), Bandırma'da sunulmuştur. Makale Gecmiși / Article History

Başvuru Tarihi / Date of Application : 30 Ağustos / August 2019

Kabul Tarihi / Acceptance Date $\quad$ : 9 Ocak / January 2020 
faizlerin yükseltilmesine rağmen döviz kurlarının hızla yükselmeye devam etmesi ${ }^{2}$ faiz oranlarının politika aracı olarak kullanıldığı istikrar programlarının etkinliğinin sorgulanmasına neden olmuştur.

Gerek teorik ve amprik literatürdeki farklı yaklaşımlar gerekse uygulanan politikaların farklı ekonomilerde farklı sonuçlar üretmesi, döviz kuru faiz ilişkisinin tüm ülkeler için geçerli, standart bir ilişki olmadığını akıllara getirmektedir. Bu nedenle, döviz kuru istikrarına yönelik politika formülasyonunda, ilgili ekonomi için geçerli faiz-döviz kuru ilişkisinin bilinmesi gerekmekte ve bu amaçla döviz kurlarının faiz oranlarına duyarlılık derecelerinin amprik olarak test edilmesi önemli hale gelmektedir. Bu bağlamda çalışmada Türkiye'de para politikası resmi faiz oranları ve piyasa faiz oranları ile döviz kuru arasındaki kısa ve uzun dönemli dinamik ilişkilerin ortaya konulması amaçlanmaktadır. Çalışmanın geri kalan kısmında öncelikle konu ile ilgili ampirik literatüre yer verilmiştir. Daha sonra ise çalışmanın metodolojisi ve kullanılan veriler tanıtılarak elde edilen ampirik bulgular paylaşılmıştır. Sonuç bölümünde ise bulgulara ilişkin değerlendirmelerde ve politika önerilerinde bulunulmuştur.

\section{Faiz Oranı ve Döviz Kuru İlişkisi: Teorik Arka Plan}

Döviz kuru ile nominal faiz oranları arasındaki ilişkiyi ele alan sistemli teorik yaklaşımlar ortaya atılmıştır. Bu yaklaşımlar birbirleri ile çelişen farklı olası sonuçlar ileri sürmektedirler. Bunlardan biri fiyatların katı olduğunu savunan Keynesyen yaklaşımdır. Keynesyen yaklaşıma göre, yapışkan fiyat varsayımının bir sonucu olarak nominal faiz oranları, para politikası duruşunun (gevşek yada sıkı) bir neticesidir. Fiyatların değişmeyeceği varsayımı altında, para talebi sabitken para arzının kısılması ulusal faiz oranının yabancı faiz oranı karşısında yükselmesine neden olacaktır. Ulusal faiz oranındaki bu artış, dışarıdan içeriye doğru sermaye girişinin artmasına, böylelikle döviz kurunun düşmesine ve ulusal paranın değer kazanmasına neden olacaktır. Bu varsayımlar altında nominal faiz oranı ile döviz kuru arasında ters yönlü bir ilişki ortaya çıkmaktadır. Diğer taraftan fiyatların tamamen esnek kabul edildiği Şikago yaklaşımına göre, esnek fiyat varsayımının bir sonucu olarak, nominal faiz oranlarındaki artışlar beklenen enflasyon oranındaki artışların bir yansıması olarak kabul edilir. Ulusal faiz oranları yabancı faiz oranlarına nispeten yükseltildiğinde, ekonomik aktörler ulusal paranın enflasyon nedeniyle değer kaybedeceği algısına kapılırlar. Bu durumda ulusal paraya olan talep azalır, yabancı paraya olan talep ise artar. Sonuç olarak döviz kuru yükselir, yerli para hemen değer kaybetmeye başlar. Bu mekanizma Şikago yaklaşımında Keynesyen yaklaşımdan farklı olarak nominal faiz oranları ile döviz kuru arasında pozitif yönlü bir ilişki ortaya çıkmaktadır (Frankel, 1979: 610).

Döviz kurlarını açıklayan en eski teori 1918 yılında İsveçli iktisatçı Gustav Cassel tarafından ortaya atılan mutlak satın alma gücü paritesidir ${ }^{3}$. Cassel bu teoriyi 1. Dünya Savaşı sonrasında ara verilen altın standardına yeniden dönüldüğünde geçerli olacak resmi kurların belirlenmesi amacı ile geliştirmiştir. Bu teoriye göre, yurt içi ve yurt dışı enflasyon oranı ile ulusal paranın dış değeri arasında ters yönlü bir ilişki söz konusudur. $\mathrm{S}$ döviz kurunu, $\mathrm{P}_{\mathrm{d}}$ yurt içi fiyat seviyesini, $P_{f}$ yurt dışı fiyat seviyesini temsil etmek üzere mutlak satın alma gücü paritesi aşağıdaki şekilde formüle edilebilir:

$\mathrm{S}=\mathrm{P}_{\mathrm{d}} / \mathrm{P}_{\mathrm{f}}$

$\mathrm{Bu}$ ifade ulusal para ile yabancı para arasındaki değişim oranını veren döviz kurunun, yurt içi ve yurt dışı fiyat seviyesi oranına bağlı olduğunu göstermektedir. Buna göre, yurt içi fiyatlar yurt dışı fiyatlara nispeten yükseldiğinde, döviz kuru da aynı oranda yükselecek ve paralel şekilde ulusal para değer kaybına uğrayacaktır (Seyidoğlu, 2013: 157159).

Döviz kurlarındaki değişimi açıklamaya çalışan bir diğer model ise 1960'ların başında Robert Mundell ve J. Marcus Fleming tarafından geliştirilen Mundell-Fleming modelidir. Mundell-Fleming modeline göre, sermaye hareketleri döviz kurlarındaki değişimi etkileyen en önemli unsurdur. Fiyatların sabit varsayıldığı bu modelde, sermaye hareketleri yurt içi ve yurt dışı faiz oranı farkına duyarlıdır. Para politikası uygulamaları sonucu faiz oranları değiştiğinde, ülkedeki yabancı sermaye miktarı ve döviz kurları değişmektedir. Bu bağlamda, genişlemeci para politikaları sonucu faiz oranının düşmesi, sermaye çıkışına yol açarak kurların yükselmesine ve ulusal paranın değer kaybetmesine neden olurken, daraltıcı para politikası ise tersi sonuçlar doğurmaktadır. Uygulanan ekonomi politikalarının, sermaye hareketleri ve döviz kurları üzerindeki etkilerini ele alan Mundell-Fleming modeli, 1970’lere kadar kur değişimlerini açıklamakta kullanılsada fiyatların sabit kabul edilmesi nedeniyle yetersiz kaldığından yeni yaklaşımlar ortaya atılmıştır (Ünsal, 2005: 386-387).

1973 sonrası Bretton-Woods sisteminin çöküşü ile birlikte sabit kur sisteminin büyük ölçüde terk edilerek esnek kur sistemine geçilmesi, döviz kurlarında aşırı dalgalanmaların meydana gelmesine neden olmuş ve bu dalgalanmalar parasalcı modeler ile açıklanmaya çalışılmıştır. Dornbusch (1976) tarafından geliştirilen ve fiyatların yapışkan ve esnek olarak kabul edildiği iki uç durumun ele alındığı parasalcı modellerde denge döviz kuru, para arz ve talebinde meydana gelen değişimler ile açıklanmaktadır. Fiyatların esnek kabul edildiği parasalcı model, döviz kurlarındaki dalgalanmayı klasik varsayımlara dayanarak açıklamaktadır. Klasik yaklaşımda fiyatlar tam esnek kabul edilirken, miktar teorisi ile ortaya konan dikotomi varsayımına göre de parasal değişkenler reel değişkenler üzerinde herhangi bir etki meydana getirmemektedir. Reel ve parasal sektörler arasındaki bu ayrım, para arzı değiştiğinde sadece fiyatlar genel düzeyinin değişmesine yol açmaktadır. Bu varsayıma göre, para arzı arttırıldığında fiyatlar serbestçe hareket ederek aynı ölçüde yükselecektir. Satın alma gücü paritesinin herzaman geçerli olduğunu kabul eden bu model, döviz kurlarının da fiyat

\footnotetext{
${ }^{2}$ Doğu Asya krizinde Endonezya, Kore ve Tayland'da krizin başlangıcında meydana gelen keskin kur artışları sıkı para politikası ve yüksek faiz oranları ile engellenmeye çalışılmıştır. Uygulanan bu istikrar programına rağmen kurlardaki yükseliş hız kesmeden devam etmiştir (Basurto ve Ghosh, 2001:99). ${ }^{3}$ Cassel bu teoriyi 1918 yilında yayımlanan "Abnormal Deviations in International Exchanges" isimli makalesinde açıklamaktadır.
} 
düzeyinde meydana gelen artış kadar yükseleceğini ve buna bağlı olarak ulusal paranın değer kaybına uğrayacağını öngörmektedir. Fiyatların katı olduğunu varsayan parasalcı modelinde ise para arzı beklenmedik bir şekilde arttırıldığında fiyatlar genel düzeyi ani bir sıçrama gösteremez. Bununla birlikte, nominal faiz oranlarının para arzındaki artış neticesinde para piyasasını dengeye getirecek şekilde düşmesi sonucu döviz kurunda ani bir sıçrama gerçekleşir. Bu modelde ilk aşamada döviz kurunda meydana gelen bu artış, fiyatların esnek kabul edildiği modelde öngörülenden daha fazla olur. Ancak, fiyatlar para arzındaki artışa karşılık anında hareket etmeseler de zamanla tepki vereceklerinden döviz kurundaki nihai artış fiyatların esnek olduğu modeldeki kadar olur (Özatay, 2015:164-168).

1980 sonrası dönemde ise finansal piyasaların liberalizasyonu ile portföy tercihlerinin döviz kurları üzerindeki etkisi artmıştır. Döviz kurlarındaki dalgalanmaları para arz ve talebindeki değişmeler ile açıklamaya çalışan parasalcı yaklaşım sermaye haraketlerinin döviz kurları üzerindeki etkisini içermemesi nedeni ile büyük ölçüde yetersiz kalmıştır. Bu eksiklik daha sonra portföy yaklaşımı ile giderilmiştir. Portföy yaklaşımında denge döviz kuru açıklanırken yalnızca para arz ve talebi değil, ekonomik aktörlerin portföylerini oluşturan tüm finansal varlıkların arz ve talebi dikkate alınır. $\mathrm{Bu}$ yaklaşımda bir ülkede yerleşik ekonomik aktörler servetlerini, ulusal para, ulusal para cinsinden finansal varlıklar ve yabancı para cinsinden finansal varlıklar arasında dağıtmaktadırlar. Portföy yaklaşımında denge döviz kuru, karar birimlerinin portföylerini oluşturan finansal varlık ve yükümlülüklerin arz ve talebindeki değişim ile açıklanır. Portföy yaklaşımına göre, bir ülkede yerleşikler servetlerini ulusal para (M), ulusal para cinsinden finansal araçlar ve yabancı para cinsinden finansal araçlar arasında dağıtmaktadır. Bu yaklaşıma göre yurt içi ve yurt dışı faiz oranı farkının artması ulusal para talebini azaltırken, yurt içi faiz oranının yükselmesi ya da yurt dışı faiz oranının düşmesi ulusal para cinsinden finansal varlık talebinde artışa neden olmaktadır. Yabancı para cinsinden finansal varlık talebi ise, yurt dışı faiz oranı yanında döviz kurunun beklenen değerine bağlı olarak değişmektedir. Portföy yaklaşımına göre yurt içi faiz oranı yükseldiğinde ulusal para birimi cinsinden varlık talebi ve buna bağlı olarak da ulusal para talebi artmaktadır. Bu durumda ulusal para değer kazanırken döviz kuru düşer. Yurt dışı faiz oranının artması ise bu süreci tersine işleterek ulusal paranın değer kaybetmesine ve döviz kurunun yükselmesine yol açar (Gacener Atış ve Utkulu, 2011:67-68).

\section{Literatür}

Literatürde döviz kuru ve faiz oranları arasındaki ilişkiyi inceleyen çok sayıda ampirik çalışmaya rağmen, söz konusu ilişkinin varlığına ya da yönüne ilişkin birbirinden farklı sonuçlara ulaşıldığı göze çarpan bir husustur. Literatürdeki bazı çalışmalar, döviz kuru ve faiz oranı arasında tahmin edilebilir bir ilişki olmadığı yönünde sonuçlara ulaşarak, faiz oranlarının döviz kurlarına istikrar kazandırmada etkin bir araç olarak kullanılamayacağını ileri sürmüşlerdir (bkz. Baig ve Goldfajn (1998), Kraay (2000), Basurto ve Ghosh (2001)). Bunun aksi yönünde bulgulara ulaşan çalışmalar ise faiz oranları kullanılarak döviz kurlarına müdahalenin doğru bir politika olacağını savunmuşlardır (bkz. Furman and Stiglitz (1998), Simone ve Razzak (1999)).

Frankel (1979), Şikago yaklaşımına göre geliştirdiği bir model çerçevesinde beklentilerin döviz kuru üzerindeki etkisini ele almıştır. Modelden elde edilen sonuçlara göre, parasal genişleme para arzının artmasına neden olarak ulusal paranın değer kaybetmesine ve döviz kurunun yükselmesine neden olmaktadır. Diğer yandan, artan para arzı sonucu beklenen enflasyon düzeyinin yükselmesi yerli paraya olan talebi azaltıp yabancı paraya olan talebi arttıracağından uzun dönemde ulusal paranın değer kaybetmesine yol açmaktadır.

Hooper ve Morton (1982), ABD'de Bretton Woods sisteminin çöküşünün ardından esnek döviz kuru sisteminin benimsendiği 1973'ten sonraki dönemde reel ve nominal döviz kurlarının hareketini Dornbusch (1976) ve Frankfell (1979) tarafından geliştirilen modellere benzer bir model kurarak analiz etmiştir. Doların, 10 büyük endüstriyel ülkenin para birimlerinden oluşan bir sepete karşı değerinin ele alındığı çalışmanın sonuçlarına göre, cari dengedeki beklenmeyen bir değişim döviz kurunun yükselmesine ve ulusal paranın değer kaybetmesine neden olmaktadır.

Döviz kurları ile faiz oranı arasındaki ilişkiyi Asya ekonomileri için ele alan, Baig ve Goldfajn (1998), 1997 Temmuz-1998 Temmuz döneminde döviz kurları ile faiz oranları arasındaki ilişkinin standart olmadığ́ yönünde bulgulara ulaşmıştır. Çalışmadaki korelasyon analizlerine göre, ele alınan ülkelerin bazılarında yüksek reel faiz oranları, reel döviz kurunun değerlenmesine yol açarken, diğer bazı ülkelerde ise ilişkinin ters yönlü olduğu sonucuna ulaşılmıştır. Diğer taraftan günlük veriler kullanılarak gerçekleştirilen regresyon analizinden faiz oranlarındaki artışın döviz kurlarının değer kaybetmesine yol açacağı beklentisini destekleyen kanıtlara ulaşılamamıştır.

Furman and Stiglitz (1998), basit regresyon analizi yaparak faiz oranı artışları ile döviz kuru değer kayıplarını ilişkilendirmeye çalışmışlardır. Elde ettikleri sonuçları ikna edici olmaktan uzak olarak değerlendiren yazarlar, buna rağmen faiz oranı artışlarının büyüklük ve süresinin döviz kurunda meydana gelecek değer kayıpları ile ilişkilendirilebileceğini ve faiz oranlarının döviz kurunu savunmak için yararlı bir araç olarak kabul edilebileceği öne sürmüşlerdir.

Simone ve Razzak (1999) ise nominal faiz oranlarının tahvil piyasasında belirlendiğinin varsayıldığı çalışmalarında, nominal döviz kurları ile faiz oranı farklılıkları arasındaki ilişkiyi ve döviz kurlarının uzun dönemli davranış özelliklerini eşbütünleşme testlerini kullanarak incelemişlerdir. ABD dolarının Alman Markı, İngiliz Poundu, Japon Yeni ve Kanada Doları ile eşleştirildiği çalışmanın sonuçlarına göre, faiz farkındaki artış ulusal paranın değer kazanmasına diğer bir ifadeyle döviz kurunun düşmesine yol açmaktadır.

Benzer sonuçlara ulaşan çalışmalardan biri olan Kraay (2000), 1960-1997 dönemi itibariyle gelişmiş ve gelişmekte olan ülkelerden oluşan geniş bir örneklem kullanarak, yüksek faiz oranlarının spekülatif saldırı altındaki döviz kurunu savunmaya yardım edip edemeyeceğini regresyon analizi yaparak sorgulamıştır. Çalışmadan elde edilen ampirik bulgular, 
faiz oranlarının yükseltilmesinin spekülatif saldırı altındaki para birimininin değerini koruyacağına dair hiçbir kanıt sunmamaktadir.

Basurto ve Ghosh (2001), Endonezya, Tayland, Kore ve Meksika için gerçekleştirleri çalışmalarında, 1990-2000 periyodu için çeyrek dönemlik verileri kullanarak, sıkı para politikası/yüksek faiz oranı ile döviz kuru değer kayıplarının ilişkili olup olmadığını araştırmışlardır. Çalışmada, Kore dışındaki ülkelerde faiz oranı artışlarının döviz kurunu düşüreceğine ilişkin sağlam kanıtlara ulaşılamamıştır.

Türkiye için faiz döviz kuru ilişkisini araştıran çalışmalar incelendiğinde de çoğunlukla iki değişken arasında öngörülebilir ve istikrarlı bir ilişki olmadığı yönünde sonuçlara ulaşıldığı görülmektedir. Türkiye için yapılmış eski çalışmalardan biri olan Karamustafa ve Küçükkale (2002), Kasım 2000 ve Şubat 2001 tarih aralığını kriz dönemi olarak ele alarak, kriz öncesi ve sonrası dönem için faiz ve döviz kuru arasındaki ilişkileri günlük veriler üzerinden Granger nedensellik testi ile incelemişlerdir. Elde edilen bulgulara göre, kriz öncesi dönemde faiz ve dolar cinsinden ifade edilen döviz kuru değişkenleri arasında hiç bir şekilde nedensellik ilişkisi bulunamazken, kriz sonrası dönemde faiz değişkeninden döviz kuru değişkenine doğru bir nedensellik tespit edilmiştir.

Cho ve West (2003), faiz oranlarındaki dışsal bir değişimin döviz kurları üzerindeki etkisinin araştırıldığı çalışmalarında Kore, Filipinler ve Tayland için 1997-1998 dönemine ait haftalık verilerle iki denklemli bir model kullanarak tahminlerde bulunmuşlardır. Elde edilen sonuçlara göre faiz oranlarında meydana gelen artışlar Kore ve Filipinler'de döviz kurunun değerlenmesine neden olurken, Tayland'da ise değer kaybetmesine neden olmaktadır.

Karaca (2005), 1990:01-2005:07 dönemine ait aylık verileri kullanarak Türkiye’de döviz kuru ve faiz oranı arasındaki ilişkiyi ARDL sınır testi analiz etmiştir. Bu çalışmadan elde edilen sonuçlarda ise ilgili dönem için döviz kuru ve faiz oranı arasında anlamlı bir ilişki tespit edilememiştir.

Türkiye'de nominal döviz kurları ile faiz oranları arasındaki ilişkiyi 1984- 2006 dönemi için araştıran Gül, Ekinci ve Özer (2007) ise Granger nedensellik ve eşbütünleşme teknikleri kullanılarak elde edilen sonuçlarda, faiz oranlarından döviz kuruna doğru anlamlı bir nedensellik tespit edemediklerini ifade etmişlerdir. Buna karşın döviz kurundan faiz oranına doğru ise tek yönlü anlamlı bir nedensellik bulunmuştur. Diğer taraftan yapılan eşbütünleşme testi sonucunda nominal döviz kurları ile faiz oranları arasında eşbütünleşme ilişkinin olmadığı görülmüştür.

Gacener Atış ve Utkulu (2011), portföy yaklaşımına göre oluşturdukları model ile 1987:1-2008:4 dönemi için Türkiye' deki yatırımcıların portföylerinde yer alan varlık tercihlerinin denge döviz kuru üzerindeki etkisi Markov Rejim Değişimi modeli ile analiz edilmiştir. Döviz kurunun istikrarsız (rejim 1) ve istikrarlı (rejim 2) kabul edildiği iki rejimli bir sürecin tanımlandığı çalışmanın sonuçlarına göre, rejim 1'de, ekonomik karar birimlerinin portföy tercihleri, denge döviz kurunun değişimi üzerinde etkili bulunmazken, rejim 2'de, tercihlerin denge döviz kurundaki değişimleri açıklama gücü daha yüksek bulunmuştur.

Oruç (2016), döviz kurunun belirlenmesinde parasalcı yaklaşımı ele alan çalışmasında eşbütünleşme ve dinamik en küçük kareler yöntemlerini kullanarak 1988 - 2015 dönemine ait çeyrek dönemlik verilerler döviz kuru ile nispi para arzı, nispi gelir düzeyi, nispi faiz oranı ve nispi enflasyon değişkenleri arasındaki ilişkileri Türkiye ekonomisi için analiz etmiştir. Çalışmanın bulgularına göre nispi gelir döviz kuru üzerinde en belirleyici değişkendir. Buna karşın nispi faiz ve nispi enflasyon oranı değişkenlerinin döviz kuru üzerinde anlamlı bir etkilerinin olmadığı saptanmıştır.

Diğer taraftan Ayla (2019), 2006-2017 dönemi için 3 aylık verilerle kısa vadeli reel faiz oranları ve döviz kurları arasındaki ilişkiyi eşbütünleşme ve nedensellik testlerini kullanarak araştırmışlardır. Engle-Granger eşbütünleşme testi sonucunda kısa dönemli reel faiz oranları ile ortalama döviz kuru arasında eşbütünleşme ilişsisi tespit edilmiştir. Nedensellik analizinden elde edilen bulgulardan ise değişkenlerin kısa dönemde karşılıklı nedensellik ilişkisi içinde olmadığı, ancak uzun dönemde karşılıklı nedensellik ilişkisinin olduğu sonucuna ulaşılmıştır.

\section{Veri Seti, Metodoloji ve Bulgular}

Bu çalışmada nominal döviz kuru ile TCMB'nin resmi faiz oranları ve gösterge tahvil faiz oranı arasındaki dinamik ilişkiler, 2011:01 ile 2018:05 dönemi için ait aylık veriler ile Granger Nedensellik, Etki Tepki Fonksiyonları ve ARDL eşbütünleşme testleri kullanılarak araştırılmıştır.

Literatürde döviz kuruna ilişkin modellemelerde en uygun faiz oranının (kısa dönem faiz oranı ya da uzun dönem faiz oranı) hangisi olduğu yönüde bir uzlaşı bulunmamaktadır. Örneğin Frankfel (1979) uzun dönem faiz oranlarını kullanırken, Meese ve Rogof (1988), hem kısa hem de uzun dönem faiz oranlarını, Cumby ve Obstfeld (1982) ise kısa dönem faiz oranlarını tercih etmiştir. Bu nedenle, çalışmada faiz değişkeni olarak hem TCMB'nin resmi faizleri olan politika faiz oranı ve ortalama fonlama maliyeti hem de piyasa faizini temsil etmesi açısından 2 yıllık gösterge tahvil faiz oranı kullanılmışır. Nominal döviz kuru değişkeni olarak ise ABD doları karşılığı Türk Lirası şeklinde oluşturulan gösterge satış kuru kullanılmıştır. Veriler TCMB elektronik veri dağıtım sistemi üzerinden elde edilmiştir. Çalışmadaki tüm değişkenlerin logaritmik dönüşümleri yapıldıktan sonra analize dahil edilmiştir. 
Güler, A. / Journal of Yasar University, 2020, 15/58, 337-346

Tablo 1. Değişkenlerin Açıklamaları

\begin{tabular}{|l|l|}
\hline Değişskenler & Açıklamaları \\
\hline lex & ABD Doları cinsinden Satış Kuru \\
\hline lort & TCMB ortalama fonlama maliyeti \\
\hline ldibs & Türkiye'de gösterge niteliğindeki 2 yıllık tahvil faizi \\
\hline lpint & Bir hafta vadeli repo ihale faiz oranı \\
\hline
\end{tabular}

Para politikası alanında yapılan ampirik çalışmalarda yaygın bir şekilde kullanılan Vektör Otoregresyon (VAR) modelleri, değişkenler arasında bağımlı bağımsız değişken ayrımı yapılmasına gerek bırakmaksızın karşılıklı ilişkilerin incelenmesine izin vermektedir. Sims (1980) tarafindan geliştirilen Granger nedensellik testine dayanan VAR modeli, her birini içsel kabul ederek, değişkenleri hem kendi hem de diğer değişkenlerin belli bir gecikmeye kadar olan değerleri ile ilişkilendirmektedir. Yt ve Xt gibi iki değişkenli bir VAR modeli aşağıdaki gibi gösterilebilir:

$y_{t}=\alpha+\sum_{i=1}^{q} \beta_{i} y_{t-i}+\sum_{i=1}^{q} \delta_{i} x_{t-i}+\varepsilon_{1 t}$

$x_{t}=\alpha+\sum_{i=1}^{q} \theta_{i} y_{t-i}+\sum_{i=1}^{q} \vartheta_{i} x_{t-i}+\varepsilon_{2 t}$

Denklem (1) ve (2) de $\mathrm{x}$ değişkenine ait gecikmeli değerlerin y değişenini, y değişkenine bağlı gecikmeli değerlerin de $\mathrm{x}$ değişkenini etkilediği görülmektedir. Denklemlerde q gecikme uzunluğunu, $\varepsilon$ ise hata terimlerini ifade etmektedir.

VAR modellerinde nedensellik ilişkisi Granger nedensellik testi ile araştırılmaktadır. Granger (1969)'a göre, birbirinden bağımsız hareketler arasında daima bir zaman farkı olduğundan eş anlı nedensellik söz konusu olmamaktadır. Bu nedenle değişkenler arasındaki nedensellik ilişkisi test edilirken değişkenlerin gecikmeli değerlerinin kullanılması, modelin öngörü performansını arttırmaktadır.

Sonuçların etkin ve tutarlı olması için analize dahil ediecek değişkenlerin durağan olması gerekmektedir. Granger ve Newbold (1974)'e göre durağan olmayan seriler üzerinden gerçekleştirilen analizlerde gerçekte olmayan ilişkiler varmış ortaya çıkabilmektedir. Bu nedenle ilk olarak, modellerde kullanılacak değişkenlerin durağanlık özellikleri Augmented Dickey-Fuller (ADF) (Dickey and Fuller, 1981) and Phillips-Perron (Phillips and Perron, 1988) birim kök testleri ile sınanmıştır.

Tablo 2. ADF ve Phillips-Perron Birim Kök Testi Sonuçları

\begin{tabular}{|l|l|l|l|l|l|l|l|l|}
\hline & \multicolumn{4}{|c|}{ ADF } & \multicolumn{4}{c|}{$P-P$} \\
\hline & \multicolumn{2}{|c|}{ Seviye } & \multicolumn{2}{c|}{ Birinci Fark } & \multicolumn{2}{c|}{ Seviye } & \multicolumn{2}{c|}{ Birinci Fark } \\
\hline lex & 0.54 & -2.58 & $-6.40^{*}$ & $-5.77^{*}$ & 0.57 & -1.76 & $6.13^{*}$ & $-6.21^{*}$ \\
\hline lort & -0.69 & -2.07 & $-7.94^{*}$ & $-7.96^{*}$ & -0.69 & -2.28 & $-7.88^{*}$ & $-7.90^{*}$ \\
\hline lpin & -1.93 & -2.66 & $-8.93^{*}$ & $-8.88^{*}$ & -2.05 & -2.84 & $-8.93^{*}$ & $-8.88^{*}$ \\
\hline ldib & -1.05 & -2.67 & $-8.29^{*}$ & $-8.35^{*}$ & -1.66 & -2.20 & $8.22^{*}$ & -8.28 \\
\hline
\end{tabular}

Not: (*)\% 1 istatistiksel anlamlılık düzeyini temsil etmektedir.

Birim kök testlerine ilişkin sonuçlar Tablo 2'de sunulmuştur. Gerçekleştirilen birim kök testleri sonucunda tüm değişkenler seviye değerlerinde birim kök içerdikleri tespit edilmiştir. Bu nedenle değişkenlerin hepsi birinci farkları alınarak durağanlaştırılmıştır.

Değişkenlerin durağanlık sınamasının ardından VAR modelinin tahminine geçilmiş ve öncelikle uygun gecikme sayısı belirlenmiştir.Tablo 3'de ardışı modifiye edilmiş LR testi, son kestirim hatası (FPE), Akaike bilgi kriteri (AIC) Schwarz bilgi kriteri (SIC) ve Hannan-Quinn bilgi kriteri (HQ) gibi istatistiklere göre uygun gecikme uzunlukları gösterilmektedir. Schwarz bilgi kriteri (SIC) hariç diğer tüm kriterler, uygun gecikme uzunluğunun 1 olduğuna işaret etmektedir. Bu nedenle 1 gecikmeli VAR modelinin uygun model olduğuna karar verilmiştir. VAR (1) modelinden elde edilen hata terimleri değişen varyans, otokorelasyon içermemekte ve normal dağılım şartını sağlamaktadır.

Tablo 3. VAR Modeli İçin Uygun Gecikme Uzunluğunun Belirlenmesi

\begin{tabular}{|c|l|l|l|l|l|l|}
\hline Lag & \multicolumn{1}{|c|}{$\log L$} & \multicolumn{1}{c|}{ LR } & \multicolumn{1}{c|}{ FPE } & \multicolumn{1}{c|}{ AIC } & \multicolumn{1}{c|}{$S C$} & \multicolumn{1}{c|}{$H Q$} \\
\hline 0 & 432.0225 & $N A$ & $2.65 e-10$ & -10.70056 & $-10.58146^{*}$ & -10.65281 \\
\hline 1 & $457.7654 *$ & $48.26798^{*}$ & $2.08 e-10^{*}$ & $-10.94414 *$ & -10.34863 & $-10.70538^{*}$ \\
\hline 2 & 472.2843 & 25.77102 & $2.16 e-10$ & -10.90711 & -9.835196 & -10.47735 \\
\hline 3 & 476.7204 & 7.430424 & $2.91 e-10$ & -10.61801 & -9.069692 & -9.997245 \\
\hline 4 & 482.1704 & 8.583738 & $3.84 e-10$ & -10.35426 & -8.329537 & -9.542490 \\
\hline 5 & 494.6980 & 18.47822 & $4.29 e-10$ & -10.26745 & -7.766322 & -9.264676 \\
\hline 6 & 506.8991 & 16.77659 & $4.90 e-10$ & -10.17248 & -7.194945 & -8.978700 \\
\hline 7 & 513.3344 & 8.205004 & $6.55 e-10$ & -9.933361 & -6.479422 & -8.548578 \\
\hline 8 & 527.2112 & 16.30517 & $7.41 e-10$ & -9.880279 & -5.949935 & -8.304492 \\
\hline
\end{tabular}


Şekil 1'de otoregresif karakteristik polinomunun ters köklerinin birim çember içerisinde dağıldığı görülmektedir. Buna göre tahmin edilen VAR modelinin istikrar koşulunu sağladığına karar verilmiştir.

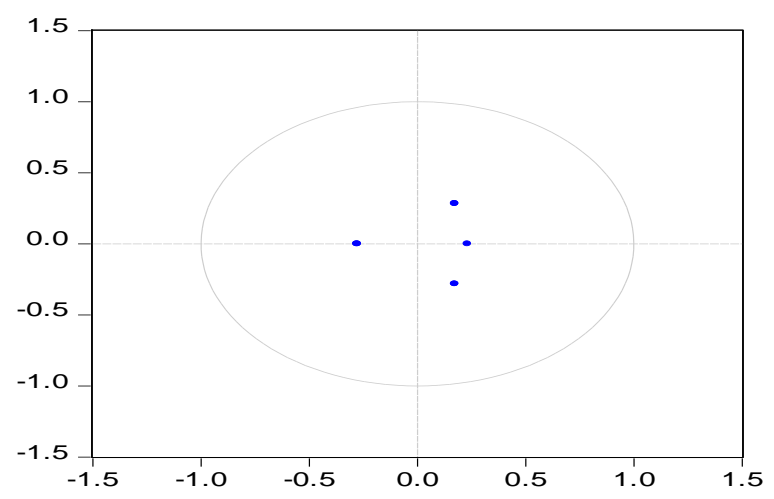

Şekil 1. Karakteristik Polinomiyal Ters Kökler

Modelin kararlılığının belirlenmesinin ardından çift yönlü Granger nedensellik testi uygulanmıştır. Sonuçlar Tablo 4' de sunulmuştur. Granger nedensellik testi sonuçlarına göre ortalama fonlama oranı (lort), politika faizi (pint) ve 2 yıllık tahvil faizinden (ldibs) döviz kuruna (lex) doğru anlamlı bir nedensellik tespit edilememiştir. Buna karşın tahvil faizinden ortalama fonlama oranına; döviz kuru ve ortalama fonlama oranından politika faizine doğru anlamlı nedensellikler tespit edilmiştir.

Table 4. Granger Nedensellik Testi Sonuçları

\begin{tabular}{|c|c|c|}
\hline & Ki-kare & P-dĕgeri \\
\hline Bă̆ımlı değişken & \multicolumn{2}{|l|}{ lex } \\
\hline $\begin{array}{l}\text { lort } \\
\text { lpint } \\
\text { ldibs } \\
\end{array}$ & $\begin{array}{l}1.179255 \\
0.087665 \\
3.819517 * * * \\
\end{array}$ & $\begin{array}{l}0.2775 \\
0.7672 \\
0.0507 \\
\end{array}$ \\
\hline Bağımlı değişken & \multicolumn{2}{|l|}{ lort } \\
\hline $\begin{array}{l}\text { lex } \\
\text { lpint } \\
\text { ldibs } \\
\end{array}$ & $\begin{array}{l}0.309383 \\
9.07 E-05 \\
9.702059 * \\
\end{array}$ & $\begin{array}{l}0.5781 \\
0.9924 \\
0.0018 \\
\end{array}$ \\
\hline Bă̆ımlı değişken & \multicolumn{2}{|l|}{ lpint } \\
\hline $\begin{array}{l}\text { lex } \\
\text { lort } \\
\text { ldibs }\end{array}$ & $\begin{array}{l}4.730227 * * \\
18.40023 * \\
2.477713\end{array}$ & $\begin{array}{l}0.0296 \\
0.0000 \\
0.1155 \\
\end{array}$ \\
\hline Bağımlı değişken & \multicolumn{2}{|l|}{ ldibs } \\
\hline $\begin{array}{l}\text { lex } \\
\text { lort } \\
\text { lpint }\end{array}$ & $\begin{array}{l}0.002027 \\
0.655079 \\
1.447431\end{array}$ & $\begin{array}{l}0.9641 \\
0.4183 \\
0.2289 \\
\end{array}$ \\
\hline
\end{tabular}

Not: *, \%1 anlamlılık düzeyini; **, \%5 anlamlılık düzeyini ***, \%10 anlamlılık düzeyini göstermektedir.

Etki tepki fonksiyonları ile elde edilen grafikler değişkenlere verilen bir standart sapmalık şokun diğer değişkenler üzerindeki etkisinin yönünü ve bu etkinin derece ve süresini göstermektedir. Etki tepki fonksiyonları hangi değişkene verilen şokun diğer değişkenler üzerinde etkili olduğunu ve dolayısı ile bu değişkenlerin bir politika aracı olarak kullanılıp Şekil 2'de görüldüğü gibi; döviz kuru değişkeni yalnızca kendisine ve tahvil faizine verilen şoklardan anlamlı şekilde etkilenmektedir. İlk grafik incelendiğinde, döviz kuru değişkenine verilen bir standart sapmalık şokun kendisini üç dönem pozitif yönde etkilediği ancak etkinin azalarak devam ettiği, 3. dönemden sonra ise anlamsılaşarak ortadan kaybolduğu anlaşılmaktadır. Tahvil faizine verilen bir standart sapmalık şok ise döviz kurunu bir dönem gecikmeli olarak önce artan sonra azalan şekilde pozitif yönde etkilemekte, bu etki 4. dönemden sonra ortadan kaybolmaktadır. Politika faizi ve ortalama fonlama oranına verilen şoklara karşı döviz kurunun anlamlı bir tepki vermediği şekil 2'de izlenebilmektedir. 

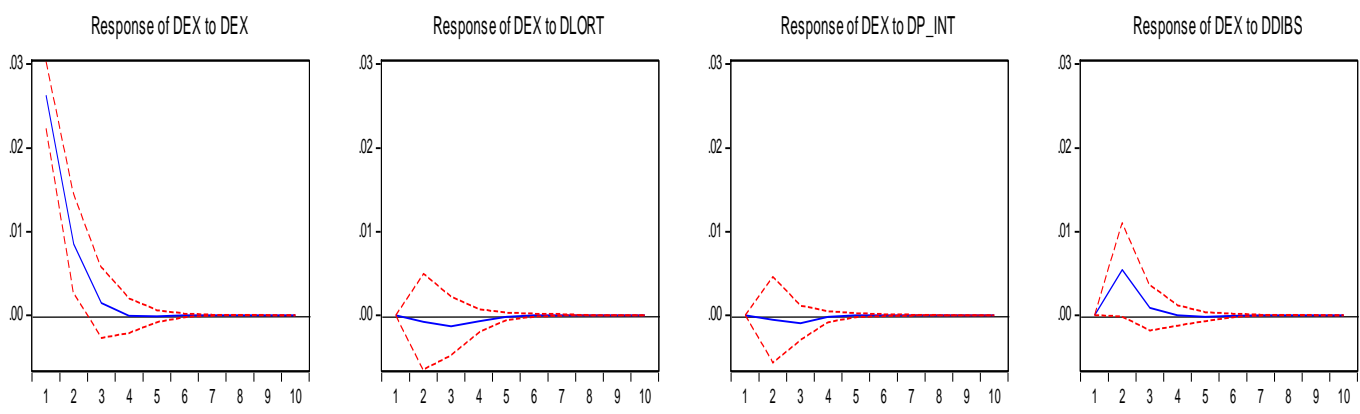

Şekil 2. Etki-Tepki Fonksiyonları

Nedensellik testi ve etki- tepki analizinden elde edilen sonuçlardan sonra değişkenler arasındaki kısa ve uzun dönemli dinamik ilişkiler ARDL sınır testi ile incelenmiştir. Değişkenler arasındaki uzun dönemli ilişkiyi incelemek için kullanılan Engle ve Granger (1987) tarafindan geliştirilen Engle-Granger eşbütünleşme testi, Johansen (1988) ve Johansen ve Juselius (1990) tarafından geliştirilen Johansen eşbütünleşme testleri tüm serilerin seviye değerlerinde birim kök içermesini ve aynı derecede farkı alındıklarında durağan hale gelmesi koşulunu içermektedir. Paseran ve diğ. (2001) tarafından geliştirilen ARDL sınır testi ise farklı derecelerde durağan olan seriler arasındaki eşbütünleşme ilişkisinin araştırılmasına izin vermektedir. ARDL sınır testine ilişkin çalışmanın değişkenlerine uyumlaştırılmış Kısıtlanmamış Hata Düzeltme Modeli (Unrestricted Error Correction Model, UECM) (3) numaralı denklemde gösterilmiştir.

$$
\begin{aligned}
\Delta \text { lex }_{t} & =\beta_{0}+\sum_{i=1}^{k} \beta_{1 i} \Delta \text { lort }_{t-i}+\sum_{i=0}^{p} \delta_{i} \Delta \text { lpint }_{t-i}+\sum_{i=0}^{q} \varphi_{i} \Delta \text { ldibs }_{t-i}+\gamma_{i} \text { lex }_{t-1}+\varepsilon_{i} \text { lort }_{t-1}+\theta_{i} \text { lpint }_{t-1}+ \\
\alpha_{i} \text { ldibs }_{t-1} & +u_{t}
\end{aligned}
$$

ARDL sınır testinde öncelikle değişkenler arasında eşbütünleşme ilişkisinin varlığı hesaplanan F istatistiği ile test edilmektedir. Hesaplanan F istatistiğinin Paseran ve diğ. (2001) tarafindan hesaplanan üst kritik değeri aşması durumunda değişkenlerin eşbütünleşik olduğuna; alt sınırın altında kalması durumunda ise değişkenlerin eşbütünleşik olmadığına karar verilmektedir. Sınır testinde hesaplanan F istatistiğinin alt ve üst kritik değerler arasında kalması durumunda ise eşbütünleşme ilişkisinin varlığına ya da yokluğuna ilişkin bir karar verilememektedir. Tablo 5'te görüldüğü gibi $\mathrm{F}$ istatistik değeri 21.46 olarak hesaplanmıştır. Bu değer \%1 anlamlık seviyesinde üst sınır değeri olan 5.61 eşiğinin üstündedir. Bu nedenle $\mathrm{H} 0$ hipotezi red edilerek değişkenler arasında eşbütünleşme ilişkisi olduğuna karar verilmiş, kısa ve uzun dönem katsayıların hesaplanmasına geçilmiştir.

\begin{tabular}{|c|c|c|}
\hline $\begin{array}{l}\text { Model } \\
F \text { Istatistiğ } i \\
k\end{array}$ & \multicolumn{2}{|c|}{$\begin{array}{l}A R D L(2,0,0,0) \\
21.46^{*} \\
3\end{array}$} \\
\hline Kritik Değerler & Alt Sinır & $\ddot{U} s t$ Sinır \\
\hline $\begin{array}{l}\% 1 \\
\% 5 \\
\% 10 \\
\end{array}$ & $\begin{array}{l}4.29 \\
3.23 \\
\quad 2.72 \\
\end{array}$ & $\begin{array}{l}5.61 \\
4.35 \\
3.77 \\
\end{array}$ \\
\hline
\end{tabular}

Table 5. Sınır Testi İçin F İstatistiği ve Kritik Değerler

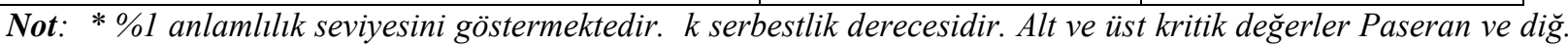
(2001:301) Tablo CI (V)'den alınmıştır.

Tablo 6, kurulan modele ilişkin tanısal test istatistiklerini göstermektedir. Tablo 6'ya göre kurulan ARDL modelinde otokorelasyon, model kurma hatası ve değişen varyans sorunları yoktur.

Tablo 6. Tanısal Test Sonuçları

\begin{tabular}{l|l}
\hline \hline Seçilen Model & ARDL (2, 4, 3, 3, 3) \\
Düzeltilmiş $R^{2}$ & 0.54 \\
F istatistiği & $10.53^{*}(0.00)$ \\
Breusch-Godfrey LM Test & $0.64(0.52)$ \\
Ramsey Reset & $0.27(0.78)$ \\
ARCH Testi & $0.33(0.56)$ \\
Jarque-Bera & $0.45(0.64)$ \\
\hline
\end{tabular}

Not: Parantez içindeki rakamlar olasılık değerleridir. *\%1 istatistiksel anlamlılık seviyesini göstermektedir.

Değişkenler arasındaki uzun dönemli ilişki için çözülen ARDL modeli (4) numaralı denklemde gösterilmiştir. 


$$
\Delta \text { lex }_{t}=\beta_{0}+\sum_{i=1}^{k} \beta_{1 i} \Delta \operatorname{lort}_{t-i}+\sum_{i=0}^{p} \delta_{i} \Delta \operatorname{lpint}_{t-i}+\sum_{i=0}^{q} \varphi_{i} \Delta \operatorname{ldibs}_{t-i}++u_{t}
$$

Tablo 7. Uzun Dönem Katsayıları

\begin{tabular}{llll}
\hline Dĕ̌işkenler & Katsayl & t istatistiği & Olasilık \\
\hline lort & 0.043559 & 0.858992 & 0.3928 \\
lpint & -0.030491 & -1.320045 & 0.1904 \\
ldibs & $0.172119^{*}$ & 4.445163 & 0.0000 \\
\hline Not: &
\end{tabular}

Not: *\%1 istatistiksel anlamlilık seviyesini göstermektedir.

Tablo 7 ARDL modeli için hesaplanan uzun dönem katsayılarını göstermektedir. Tablo 7’ye göre ortalama fonlama oranı (lort) ve tahvil faizi (ldibs) değişkenlerine ilişkin katsayılar pozitif, politika faizine ilişkin katsayı ise negatif bulunmuştur. Bununla birlikte sadece tahvil faizine ilişkin katsayının \%1 seviyesinde anlamlı olduğu görülmektedir. Elde edilen bu sonuca göre etki tepki analizinden elde edilen sonuçları destekler şekilde yalnızca tahvil faizi ile döviz kurları arasında pozitif ve istatistiksel olarak anlamlı bir ilişki söz konusudur.

Uzun dönemli katsayıların hesaplanmasının ardından değişkenler arasındaki kısa dönemli ilişkileri incelemek amacıyla hata düzeltme modeli (Error Correction Model, ECM) kurulmuştur. Hata düzeltme modelinden elde edilen hata düzeltme katsayısı $\left(e c_{t-1}\right)$, kısa dönemli dengeden sapma durumlarının ne kadarının uzun dönemde ortadan kalkacağını göstermektedir. Bu katsayısının negatif ve anlamlı olması beklenmektedir. Çalışmaya uyarlanmış hata düzeltme modeli (5) numaralı denklemde gösterilmiştir:

$$
\Delta \text { lex }_{t}=\beta_{0}+\gamma_{i} e c_{t-1}+\sum_{i=1}^{k} \beta_{1 i} \Delta \text { lort }_{t-i}+\sum_{i=0}^{p} \delta_{i} \Delta \text { lpint }_{t-i}+\sum_{i=0}^{q} \varphi_{i} \Delta \text { ldibs }_{t-i}++u_{t}
$$

Tablo 8. Hata Düzeltme Modeli Sonuçları

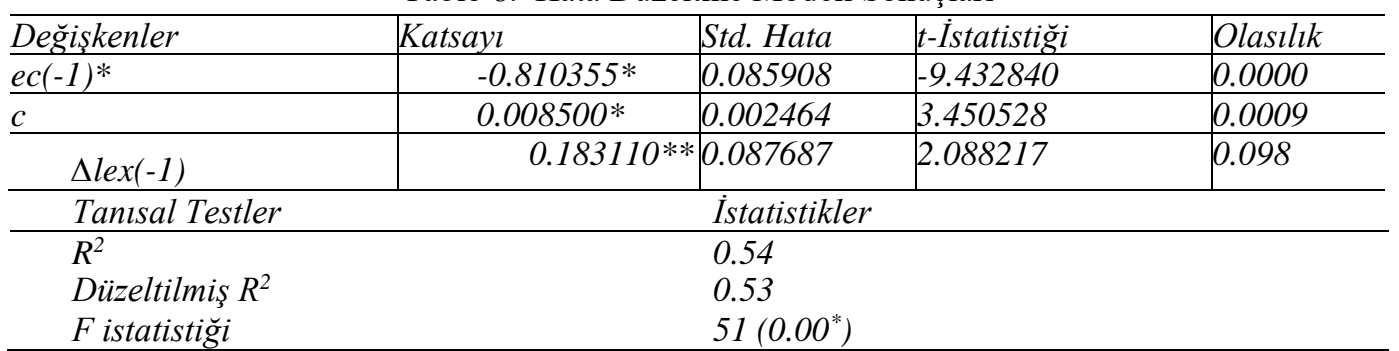

Not:*, \%1 anlamlılık düzeyini; **, \%5 anlamlllık düzeyini göstermektedir.

Tablo 8'de ARDL modeline ilişkin tahmin edilen hata düzeltme modeli sonuçları gösterilmektedir. Modelden elde edilen hata düzeltme katsayısı beklendiği gibi negatif ve anlamlı bulunmuştur [ec(-1) = -0.81]. Buna göre değişkenler arasında meydana gelen kısa dönemli dengesizlerin \% 0.81 'i ilk dönemde ortadan kalkmakta ve yaklaşı 1.23 dönem sonra tekrar denge durumuna yaklaşılmaktadır (1/0.81=1.234). Son olarak, modelin kararlılığı ve yapısal kırılmaların olup olmadığı Cusum ve CusumSQ testleri ile sorgulanmıştır. Şekil 3 incelendiğinde Cusum ve CusumSQ istatistiklerinin \%5 anlamlılık düzeyinde kritik değerler içinde kaldığı görülmektedir. Buna göre tahmin edilen modelin kararlı olduğu sonucuna ulaşılmıştır.
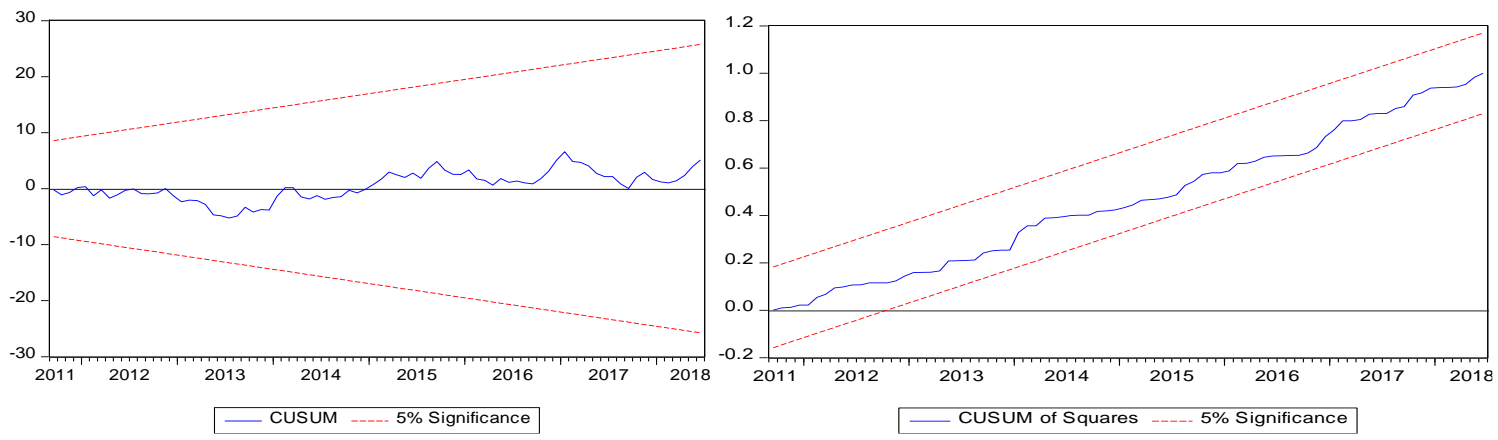

Şekil 3. Cusum ve CusumSQ Testleri

\section{Sonuç}

Faiz oranları ile döviz kurları arasındaki ilişkiyi ele alan teorik yaklaşımlar birbirinden farklı sonuçlar ileri sürmektedir. Fiyat katılı̆̆ını savunan Keynesyen yaklaşım, faiz oranı ile döviz kuru arasında ters yönlü bir ilişki olduğunu savunurken, fiyat esnekliğini savunan Şikago yaklaşımı faizler ile döviz kuru arasında doğru yönlü bir ilişkinin olduğunu savunmaktadır. Keynesyen yaklaşıma göre faiz oranlarının döviz kurlarındaki yükselişi baskılamak amacıyla kullanılması uygundur. Şikago yaklaşımına göre ise bu doğru bir politika değildir. 
Güler, A. / Journal of Yasar University, 2020, 15/58, 337-346

Bu çalışmada TCMB'nin resmi faizleri ve piyasa faizi ile ABD doları cinsinden döviz kuru arasındaki kısa ve uzun dönemli dinamik ilişkiler VAR ve ARDL metodolojisi kullanılarak incelenmiştir. Nitekim gerçekleştirilen Granger nedensellik, etki-tepki analizleri ve ARDL sınır testlerinin ortak sonucu olarak TCMB'nin resmi faizleri ile döviz kurları arasında anlamlı bir ilişki yakalanamamıştır. Buna rağmen döviz kurlarının tahvil faizlerine pozitif yönlü ve anlamlı tepkiler verdiği yapılan testler sonucu anlaşılmıştır. Açık piyasa işlemleri vasıtasıyla piyasadaki tahvil fiyat ve faiz oranlarının etkilenebildiği göz önüne alındığında, TCMB'nin piyasa faizlerini yönlendirmek suretiyle döviz kurlarını dolaylı yoldan etkileyebileceği sonucuna ulaşılabilmektedir. Bu sonuca göre, para politikası faiz oranları ile döviz kurları arasında piyasa faiz oranları üzerinden dolaylı bir ilişki kurulabilmektedir. Bu bağlamda TCMB'nin resmi faiz oranları ile piyasa faiz oranları arasındaki ilişkinin kuvvetlendirilmesi önemli hale gelmektedir.

Bununla birlikte faiz oranlarının döviz kurlarına istikrar kazandırmak için bir politika aracı olarak kullanılması konusunda TCMB'nin sınırsız bir manevra alanına sahip olmadığı politika tasarımında göz önünde tutulmalıdır. Nihayetinde faiz oranlarının hem seviye hem de oynaklık olarak başta enflasyon olmak üzere pek çok makroekonomik değişkeni etkilediği ve iç ekonomik dengenin önemli bir belirleyicisi olduğu bilinen bir durumdur. Bu durumda döviz kurlarındaki oynaklığın sınırlandırılması amacı ile faiz oranlarının politika aracı olarak agresif bir şekilde kullanımı, ekonomi üzerinde arzu edilmeyen sonuçlar doğurabilecektir. 


\section{KAYNAKÇA}

Ayla, Dilara. 2019. “Türkiye’de Faiz Oranı ve Döviz Kuru İlişkisi Üzerine Bir Araştırma.” Bingöl Üniversitesi Sosyal Bilimler Enstitüsü Dergisi 9.17 : 289-308.

Baig, M. Taimur ve Goldfajn, M. Ilan. 1998. "Monetary Policy in the Aftermath of Currency Crisis: The Case of Asia." International Monetary Fund Working Paper No. 98-170.

Basurto, Gabriela ve Ghosh, Atish. 2001. "The Interest Rate-Exchange Rate Nexus in Currency Crises." International Monetary Fund Staff Papers 47: 99-121.

Cassel, Gustav. 1918. Abnormal Deviations in International Exchanges. The Economic Journal, 28(112), 413-415.

Cho, Dongchul ve West, Kenneth D. 2003. Interest Rates And Exchange Rates in the Korean, Philippine, and Thai Exchange Rate Crises. In Managing Currency Crises in Emerging Markets (Pp. 11-36). University of Chicago Press.

Cumby, Robert E. ve Obstfeld, Maurice. 1982. "International Interest-Rate and Price-Level Linkages under Flexible Exchange Rates: A Review of Recent Evidence.” NBER Working Paper No. 921 (Also Reprint No. r0567).

Dickey, David A. ve Fuller, Wayne A. 1981 "Distribution of the Estimators for Autoregressive Time Series with a Unit Root." Econometrica 49: 1057-72.

Dornbusch, Rudiger. 1976. "Expectations and Exchange Rate Dynamics." Journal of Political Economy 84(6): 11611176.

Engle, Robert F. ve Granger, Clive W. J. 1987. "Cointegration and Error Correction: Representation, Estimation and Testing." Econometrica 55 (2), 251-276.

Frankel, Jeffrey A. 1979. "On The Mark: A Theory of Floating Exchange Rates Based on Real Interest Differentials." The American Economic Review 69(4): 610-622.

Furman, Jason ve Stiglitz, Joseph E. 1988. "Economic Crises: Evidence and Insights from East Asia.” Brookings Papers on Economic Activity 2: 1-35.

Gacener Atış, Aydanur ve Utkulu, Utku. (2011). "Denge Döviz Kurunun Portföy Yaklaşımı Ile Analizi: Türkiye Örneği”. Iktisat Isletme ve Finans, 26(303), 65-84.

Granger, Clive W. J. 1969. "Investigating Causal Relations by Econometric Models and Cross-Spectral Methods." Econometrica: Journal of the Econometric Society 424-438.

Granger, Clive W. J. ve Newbold, Paul (1974). "Spurious Regressions in Econometrics.” Journal of Economics, 2, 11120.

Gül, Ekrem. Ekinci, Aykut ve Özer, Mustafa. 2007. "Türkiye'de Faiz Oranları ve Döviz Kuru Arasındaki Nedensellik İlişkisi: 1984-2006.” Iktisat Isletme ve Finans 22(251): 21-31.

Hooper, Peter ve Morton, John. 1982. "Fluctuations in the Dollar: A Model of Nominal and Real Exchange Rate Determination. Journal of international money and finance, 1, 39-56.

Johansen, Søren. 1988. "Statistical Analysis of Cointegration Vectors." Journal of Economic Dynamics and Control 12 (2-3), 231-254.

Johansen, Søren. ve Juselius, Katarina. 1990. "Maximum Likelihood Estimation and Inference on Cointegration with Applications to the Demand for Money." Oxford Bulletin of Economics and Statistics 52 (2), 169-210.

Karaca, Orhan. 2005. "Türkiye'de Faiz Oranı ile Döviz Kuru Arasındaki Ilişki: Faizlerin Düşürülmesi Kurları Yükseltirmi?”. Discussion Paper, No. 2005/14, Turkish Economic Association, Ankara.

Kraay, Aart. 2000. "Do High Interest Rates Defend Currencies During Speculative Attacks?." The World Bank Policy Research Working Paper 2267

Karamustafa, Osman ve Küçükkale, Yakup. 2002. “Türkiye'de Kriz Döneminde Kur-Faiz-Borsa İlişkilerinin Dinamik Analizi”. Banka, Mali ve Ekonomik Yorumlar Dergisi, 2002, 11: 47-56.

Meese, Richard ve Rogof, Kenneth. 1988. "Was It Real? The Exchange Rate- Interest Differential Relation Over The Modern Floating- Rate Period." The Journal of Finance 43(4): 933-948.

Oruç, Erhan. 2016. "Döviz Kurlarının Belirlenmesinde Parasalcı Yaklaşım: Türkiye Örneği.” Kocaeli Üniversitesi Sosyal Bilimler Dergisi, (32), 101-122.

Özatay, Fatih. 2011. Parasal Ikktisat: Kuram ve Politika. 4. Baskı. Ankara: Efil Yayınevi.

Pesaran, M. Hashem. Shin, Yongcheol ve Smith, Richard. J. 2001. "Bounds Testing Approaches to The Analysis of Level Relationships." Journal of Applied Econometrics 16(3): 289-326.

Phillips, Peter C. B. ve Perron, Pierre. C. 1988. "Testing for a Unit Root in Time Series Regression.” Biometrika 75: 335346.

Seyidoğlu Halil. (2013). Uluslararası Finans, İkinci Baskı, Güzem Can Yayınları, No:27, İstanbul.

Simone, Francisco. ve Razzak, Weshah. A. 1999. "Nominal Exchange Rates and Nominal Interest Rate Differentials." IMF Working Paper, 99/141: 1-41.

Sims, Christopher A. 1980. "Macroeconomics and Reality. " Econometrica: Journal of the Econometric Society 48(1): 148.

Ünsal, Erdal. M. 2007. Makro Ikktisat. 6. Bask1. Ankara: İmaj Yayınevi. 